International Journal of Social Sciences and Humanities
Available online at http://sciencescholar.us/journal/index.php/ijssh
Vol. 3 No. 3, December 2019, pages: 50 59
e-ISSN: 2550-7001, p-ISSN: 2550-701X
https://doi.org/10.29332/ijssh.v3n3.350

\title{
Effect of Conflict and Unclear Role on Auditor Performance with Emotional Quotient as Moderating Variable
}

\author{
Ni Putu Ria Arista Dewi a, I Wayan Ramantha ${ }^{b}$
}

Article history: Received 27 April 2019, Accepted: 31 August 2019, Published: 03 November 2019

\section{Correspondence Author ${ }^{\text {a }}$}

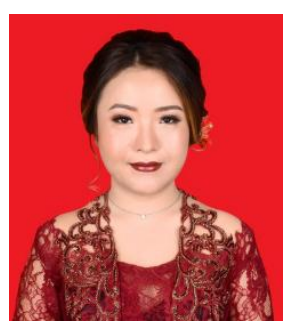

Keywords

auditor;

emotional quotient;

performance;

role conflict;

unclear role;

\begin{abstract}
This study aimed at obtaining empirical evidence about the effect of role conflict and role unclear on auditor performance and the role of emotional quotient in moderating the effect of role conflict and role unclear on auditor performance. Auditor has confronted the potential role conflicts and unclear role effects on auditor performance. A person who has a good emotional quotient can manage his/her emotions well. They are more able to control their self if it is faced on role conflicts and unclear roles in carrying out their duties or roles as an auditor. The resulting performance tends to be better. The present research was conducted in a public accounting firm in Bali. A questionnaire instrument was used as a survey method. Data analysis techniques used to test hypotheses were multiple linear regression analysis and moderated regression analysis. The number of samples was 92 respondents and used a sample determination method with a nonprobability sampling technique, namely purposive sampling. The number of questionnaires distributed was 92 copies but only 61 were returned. The results showed that role conflict has a negative effect on auditor performance, the unclear role has a negative effect on auditor performance, emotional quotient weakens the effect of role conflict on auditor performance, and emotional quotient weakens role obscurity on auditor performance.
\end{abstract}

e-ISSN: 2550-7001, p-ISSN: 2550-701X ๑ Copyright 2019. The Author. SS Journals Published by Universidad Técnica de Manabí. This is an open-access article under the CC BY-SA 4.0 license (https://creativecommons.org/licenses/by-sa/4.0/) All rights reserved.

\section{Contents}

Abstract

1. Introduction.

2. Materials and Methods

3. Results and Discussions

4. Conclusion..

a Udayana University, Denpasar, Indonesia

b Udayana University, Denpasar, Indonesia 


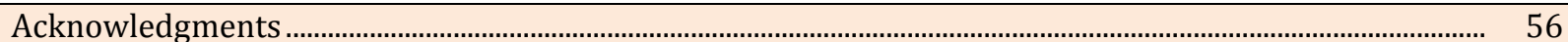

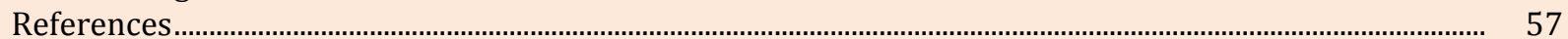

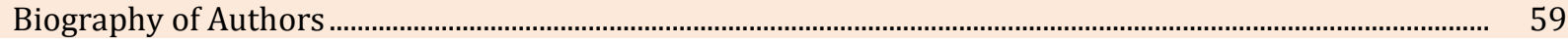

\section{Introduction}

The fulfillment of labor availability within the industrial and business world is increasingly diverse. However, the profession currently as a public accountant is one profession. It is much in demand by the public. One example is auditing. It is a professional service performed by Public Accounting Firm (PAF) and carried out by an auditor who is a service provider. PAF is needed as an independent auditor. They will make decisions not based on the interests of clients, personal, or other parties. However, it is based on facts and evidence that is collected during the assignment (Hery, 2005). Therefore, human resources in PAF is one of the most important aspects of an organization. The quality and professionalism of PAF are largely determined the auditor's working performance. The auditor's performance is the result of work achieved the auditor in carrying out their duties. It is in accordance with the responsibilities given to them and becomes one of the benchmarks used to determine whether a job performed is good or vice versa.

One of the most recent cases has occurred in Indonesia is the case of Ernst \& Young's (EY) partner public accountants in Indonesia, namely PAF Purwantono, Suherman, \& Surja who were fined US \$ 1 million (around IDR. 13.3 billion) by US regulators. They are namely the Public Company Accounting Oversight Board (PCAOB) on Thursday, February $9^{\text {th }}$, 2017. PCAOB issued a sanction or called an order of disciplinary proceedings, making findings, and imposing sanctions for the EY-Indonesia audit report on the financial statements the year ended December 31 2011 for telecommunications operator company, PT Indosat Tbk (ISAT) or Indosat Ooredoo. The finding began when the EY partner accounting firm in the US conducted a study of the audit results of accounting firms in Indonesia. They found the results of telecommunications company auditors were not supported by accurate data, namely, in the case, leasing more than four thousand cellular tower units. However, the EY affiliates in Indonesia released audit reports with unqualified status.

Another example is Bank Lippo issued two different financial statements. Wherein the two financial statements are claimed to have been audited, which in reality is not proper. Outside of Indonesia, namely America, Enron Corporation, a large company in the field of energy engineering financial statements in a matter of billion dollars. For seven years, Enron overestimated net income and covered up its debts. An independent auditor, Arthur Andersen is thought to have played a role in preparing the Enron Corporation's creative financial statements. The existence of several violations example, it is hoped in the future can be a lesson for the development of the auditor profession in Indonesia, especially, in Bali on improving performance to be better.

The auditor is often confronted with potential role conflicts that affect the auditor's performance. Role conflict is a conflict that arises due to the organization's bureaucratic control mechanism is not in accordance with norms, rules, ethics, and professional independence. It usually arises due to a mismatch of requests directed at someone from others, inside and outside the organization. The role conflict can also arise if the auditor receives several different orders and difficulty in adjusting various roles held at the same time. Ermawati et al., (2014); Aprimulki et al., (2017); Putra \& Sudana (2019), showed the role conflict has an influence on auditor performance. The study results are supported by the hypothesis in this study. The research has different results is the result of research conducted by Winidiantari \& Widhiyani (2015); Sari (2017); Saputra et al., (2019), showed the role conflict has no effect on auditor performance.

Another factor that is often faced by auditors on conducting their duties is unclear roles. The unclear role is the absence of adequate information needed for someone to carry out their role in a satisfying way. Individuals who experience unclear roles will experience anxiety, become more dissatisfied, and do work less effectively than other individuals thereby reducing their performance. Ratna \& Suryanawa (2016); Aditya (2018); Saraswati \& Badera (2018), showed the role unclear influences auditor performance. Afriana (2013), showed the unclear role had no effect on auditor performance.

The observations on the auditor's performance have previously been made by several researchers. Marlita (2014), showed the role conflict has a significant negative effect on auditor performance while role unclear,

Dewi, N. P. R. A., \& Ramantha, I. W. (2019). Effect of conflict and unclear role on auditor performance with emotional quotient as moderating variable. International Journal of Social Sciences and Humanities, 3(3), 50-59. https://doi.org/10.29332/ijssh.v3n3.350 
the impression of environmental uncertainty, motivation, and locus of control do not affect auditor performance. In contrast to Hanna \& Friska (2014), showed the role conflict did not significantly influence auditor performance. The findings showed inconsistencies between the study result to others. It is to indicate the existence of other variables that affect the relationship between role pressure on auditor performance.

Govindarajan (1986), stated the differences of the study results can be resolved through a contingency approach. It is done by including other variables that might affect the unclear role and role conflict with auditor performance. Therefore, in this study moderation variables added namely emotional quotient. It is thought to have an influence between unclear role and role conflict with auditor performance.

Emotional quotient $(E Q)$ is the ability to recognize one's own feelings, the feelings of others, motivate themselves, and manage emotions well in their self and in relationships with others. Yustiarti \& Hasan (2016), examined the effect of role conflict, unclear role, and overload role on the auditor performance with emotional quotient as a moderator. The study results showed the emotional quotient is a moderating variable between role conflict and unclear role in auditor performance. Widyastary et al., (2014) \& Rahmawati (2011), showed similar results, namely emotional quotient able to moderate the effect of role conflict and unclear role on auditor performance. In contrast to Afifah (2015), examined the influence of role conflict, unclear role, selfefficacy, professional ethics sensitivity on auditor performance with emotional quotient as a moderating variable. The study results showed the emotional quotient can be a moderating variable for role conflict, selfefficacy, professional ethical sensitivity, but cannot be a moderating variable for the unclear role. Susatmoko \& Sasongko (2017), showed similar results, namely emotional intelligence does not moderate the interaction between unclear role on auditor performance.

Researchers hope the existence of the emotional quotient variable. We can contribute to improving research or research results to be more consistent. This is expected to be one of the keys to getting out of this pressure. Therefore, the auditor can improve his performance going forward.

PAF is the object of research in Bali Province. We are interested in examining this object due to the number of PAF in Bali is increasing every year. The number of auditors is also increasing. PAF is expected, there is a clear organizational structure. Thus, auditors can clearly know the role they have. Due to not all implemented PAF a complete organizational structure. Another reason for choosing auditors of PAF in Bali as respondents were because previous studies on the influence of role conflict and unclear role on auditor performance focused on auditors outside Bali, for example, Jakarta and Surabaya, etc. However, no one has focused their research on PAF auditors in Bali.

\section{Literature Review and Hypothesis}

Role theory is a theory which is a combination of theory, orientation, as well as scientific disciplines. The psychology and role theory started with sociology and anthropology (Sarwono, 2012). These sciences, the term 'role' is taken from the theater term. An actor in the theater must play as a certain character and in his/her position as a character s/he is expected to behave in a certain way. Work performance is the quality and quantity of work achieved by an employee on carrying out their duties in accordance with the responsibilities given (Mangkunegara, 2009). The contingency approach used is in order to provide input for factors that should be considered in the research design. It is used attracting many researchers due to they want to know whether the level of reliability on the independent variable always has the same effect on each condition or not on the dependent variable.

Auditor performance is the result of the work performance implementation and responsibility of an auditor based on the ability, responsibility, and objectivity in carrying out the audit. Role conflict is a situation arises if the auditor feels difficulty in adjusting various roles held at the same time.

The unclear role is a situation wherein the information of a role/job owned by the auditor is not clear enough to achieve the desired results. The EQ is the ability to recognize one's own feelings, the feelings of others, motivate themselves, and manage emotions well in their self and in relationships with others.

The auditors have often confronted the potential role conflicts and the unclear role that affect auditor performance. Role conflict usually arises due to a mismatch of requests directed at someone from others inside and outside the organization. The role conflict can also arise if the auditor receives several different orders and difficulty in adjusting various roles held at the same time. The role conflict and unclear role factor can also affect auditor performance. A person who experiences unclear roles tends to experience a decrease in 
physical and psychological health because role unclear is one of the factors that can cause work stress due to obstruction of an employee in carrying out their duties. A job is not based on the ability of emotional intelligence will lead to a decrease in auditor performance. If a person feels pressure on the working role, of course, it has an impact on the results of the work done. The EQ is very important due to a person who has high emotional intelligence is able to better recognize emotions and thoughts that are happening to him/her.

Ermawati et al., (2014); Aprimulki et al., (2017), showed the role conflict has an influence on auditor performance. Winidiantari \& Widhiyani (2015), showed the role conflict has no effect on auditor performance. Ratna \& Suryanawa (2016); Aditya (2018); Saraswati \& Badera (2018), showed the unclear role affected auditor performance. However, Afriana (2013), showed the unclear role did not affect auditor performance. Yustiarti \& Hasan (2016), examined the effect of role conflict, unclear role, and overload role on the auditor performance with emotional quotient as moderating, the study results indicated the emotional quotient is a moderating variable between role conflict on auditor performance. Widyastary et al., (2014); Rahmawati (2011); Ilman (2017); \& Patria \& Rusli (2016), showed similar results the emotional quotient was able to moderate the influence of role conflict on auditor performance. However, Afifah (2015); Susatmoko \& Sasongko (2017), stated the emotional quotient is not a moderating variable to the relationship between unclear role and auditor performance.

Role conflict influences auditor performance. Auditors who experience role conflict in the audit process is being carried out, then the auditor is likely to feel uncomfortable when working. They will have an impact on performance namely the performance will experience a decline. Ermawati et al., (2014); Aprimulki et al.,(2017), showed the role conflict has an influence on auditor performance. The study results supported the hypothesis in this study. The research has different results Winidiantari \& Widhiyani(2015); Sari (2017), showed the role conflict has no effect on auditor performance.

H1: Role conflict has a negative effect on auditor performance.

Unclear role influences auditor performance. Auditors who experience or face unclear roles in carrying out their roles as an auditor. The auditor will experience anxiety, dissatisfaction, and lack effective in carrying out their duties. Therefore, auditors who experience unclear roles will tend to experience a decrease in performance. Ratna \& Suryanawa (2016); Aditya (2018); \& Saraswati \& Badera (2018), showed the unclear role influences auditor performance. However, Afriana (2013), showed the unclear role did not affect auditor performance.

H2: Unclear role has a negative effect on auditor performance.

Emotional quotient moderates the influence of role conflict on auditor performance. Role conflict can cause discomfort working and can reduce work motivation due to it has a negative effect on individual behavior. Amilin (2017), stated the influence of emotional intelligence on the relationship of role conflict and performance. It is expected a person faced with role conflict can carry out their duties properly. Due to the emotional intelligence are social skills for conflict management. Thus, negotiation and disagreement can be done for the same purpose. Yustiarti \&Hasan (2016); Widyastary et al., (2014); \& Rahmawati (2011), showed the emotional quotient was able to moderate the influence of role conflict on auditor performance.

H3: Emotional quotient is able to weaken the influence of role conflict on auditor performance

The emotional quotient moderated the influences of an unclear role in auditor performance. The auditor needs a high emotional quotient due to the auditor's work environment will interact with many people inside and outside. The audit process carried out by the auditor has the potential for role uncertainty that causes anxiety, discomfort, and a negative effect on the auditor's behavior. It is deemed necessary for an auditor to have an emotional quotient. The emotional quotient can play an important role in shaping the moral discipline of the auditor and regulating emotions contained in the individual auditor. The auditor's work world, various problems, and challenges must be faced unlike the intense competition, task demands, uncomfortable working atmosphere, and relationship problems with others. Ilman (2017); Patria \& Rusli (2016), showed the results that emotional intelligence moderates the influence of role unclear on auditor performance. Afifah (2015); Susatmoko \& Sasongko (2017), showed that emotional intelligence is not a moderating variable to the relationship between unclear role and auditor performance.

H4: Emotional quotient is able to weaken the influence of role unclear on auditor performance.

Dewi, N. P. R. A., \& Ramantha, I. W. (2019). Effect of conflict and unclear role on auditor performance with emotional quotient as moderating variable. International Journal of Social Sciences and Humanities, 3(3), 50-59. https://doi.org/10.29332/ijssh.v3n3.350 


\section{Materials and Methods}

The population in the current study is all auditors who work at a public accountant firm in Bali. The purposive sampling method is used. It used in accordance with the objectives of the conducted research. The study used multiple linear regression analysis techniques and moderated regression analysis using statistical product and service solution (SPSS) program.

\section{Regression Equation I}

The regression equation generated based on the multiple linear regression model.

$Y=\alpha+\beta_{1} X_{1}+\beta_{2} X_{2}+e$

Information:

$\mathrm{Y} \quad=$ Auditor performance

$\alpha \quad=$ Constant

$\beta_{1}, \beta_{2}, \quad=$ Regression coefficient

$\mathrm{X}_{1} \quad=$ Role conflict

$\mathrm{X}_{2} \quad=$ Unclear role

e $\quad=$ Standard error

\section{Equation Regression II}

The regression equation generated based on the moderation regression model.

$Y=\alpha+\beta_{1} X_{1}+\beta_{2} X_{2}+\beta_{3} X_{3}+\beta_{4} X_{1} X_{3}+\beta_{5} X_{2} X_{3}+e$

Information:

$\mathrm{Y}=$ Auditor Performance

$\alpha \quad=$ Constant

$\beta_{1}-\beta_{5}=$ Regression Coefficient

$\mathrm{X}_{1} \quad=$ Role Conflict

$\mathrm{X}_{2} \quad$ = Unclear Role

$\mathrm{X}_{3} \quad=$ Emotional Quotient

$\mathrm{X}_{1} \mathrm{X}_{3}=$ Interaction between Role Conflict with Emotional Quotient

$\mathrm{X}_{2} \mathrm{X}_{3} \quad=$ Interaction between Learning Behavior and Emotional Quotient

$\mathrm{e} \quad=$ Standard error

\section{Results and Discussions}

The questionnaire was distributed to $13 \mathrm{PAF}$ in Bali Province. There were 92 distributed questionnaires and only 61 questionnaires were returned and can be used. 31 questionnaires were not returned. There are two PAFs that are no longer operational, namely PAF Drs. Ida Bagus Djagera and PAF Rama Wendra. They did not receive the questionnaire. One PAF did not return the questionnaire was PAF Drs. Sri Marmo Djogosarkoro. Due to the busyness of auditors in the PAF, while some questionnaires were not returned to other PAFs due to the auditor was busy with the deadline for completing the audit process and dropped to the client.

Table 1

The descriptive statistics results

\begin{tabular}{llllll}
\hline & $\mathrm{N}$ & Minimum & Maximum & Mean & $\begin{array}{l}\text { Std. } \\
\text { Deviation }\end{array}$ \\
\hline Role Conflict $\left(\mathrm{X}_{1}\right)$ & 61 & 14.00 & 25.00 & 19.5738 & 2.72922 \\
\hline
\end{tabular}




\begin{tabular}{llllll}
\hline Unclear Role $\left(\mathrm{X}_{2}\right)$ & 61 & 15.00 & 24.00 & 18.5902 & 2.08468 \\
Emotional Quotient $\left(\mathrm{X}_{3}\right)$ & 61 & 41.00 & 72.00 & 59.7869 & 8.55592 \\
Auditor Performance (Y) & 61 & 9.00 & 22.00 & 17.3443 & 2.22025 \\
Valid N (listwise) & 61 & & & \\
\hline \multicolumn{5}{l}{ Source: processed data (2019) }
\end{tabular}

Source: processed data (2019)

Table 1 shows that the role conflict variable (X1) has 14.00 is the lowest value and the highest value is 25.00 with an average value is 19.5738, which ranged on 18.4 - 20.6 means the role conflict has moderate criteria to $\mathrm{PAF}$ in Bali. The unclear role variable (X2) has 15.00 is the lowest value and the highest value is 24.00 with an average value is 18.5902, which ranged on 18.6 - 20.4. It means the unclear role has moderate criteria for PAF in Bali. Variable emotional quotient (X3) has 41.00 is the lowest value and the highest value is 72.00 , an average value is 59.7869, ranged on 59.6 - 65.8. It means emotional quotient has a high criterion for PAF in Bali. The auditor performance variable $(\mathrm{Y})$ has 9.00 is the lowest value and the highest value is 22.00 , an average value is 17.33443, ranged on 16.8 - 19.4. It means emotional quotient has high criteria for PAF in Bali.

Table 2

The results of multiple regression analysis

\begin{tabular}{|c|c|c|c|c|c|}
\hline \multirow{2}{*}{ Variable } & \multicolumn{2}{|c|}{$\begin{array}{c}\text { Unstandardized } \\
\text { Coefficient }\end{array}$} & \multirow{2}{*}{$\begin{array}{l}\text { Standardized } \\
\text { Coefficient } \\
\text { Beta }\end{array}$} & \multirow[t]{2}{*}{$\mathrm{t}$} & \multirow{2}{*}{ Sig } \\
\hline & $\mathrm{B}$ & Std. Error & & & \\
\hline Constant & 27,155 & ,934 & & 29,084 & 000 \\
\hline $\mathrm{X} 1$ &,- 583 & 098 &,- 506 & $-5,933$ & 000 \\
\hline $\mathrm{X} 2$ &,- 445 & 085 &,- 448 & $-5,261$ & 000 \\
\hline Adjusted $R_{\text {square }}$ & \multicolumn{2}{|c|}{0,704} & & & \\
\hline $\mathrm{F}_{\text {count }}$ & \multirow{2}{*}{\multicolumn{2}{|c|}{ 72,437 }} & & & \\
\hline Sig. $F_{\text {count }}$ & & & & & \\
\hline
\end{tabular}

Based on the calculation results in Table 2, the multiple linear regression equation can be arranged as follows.

$$
\begin{aligned}
& \mathrm{Y}=\mathrm{a}+\mathrm{b}_{1} \mathrm{X}_{1}+\mathrm{b}_{2} \mathrm{X}_{2} \ldots \ldots \ldots \ldots \ldots \ldots \ldots \ldots \ldots \ldots \ldots \ldots \ldots \ldots \ldots \\
& \mathrm{Y}=27,155-0,583 \mathrm{X}_{1}-0,445 \mathrm{X}_{2} \ldots
\end{aligned}
$$

1) Hypothesis test I (H1)

Table 2 shows the results of the $\mathrm{X} 1$ regression coefficient are -0.583 with a significance level is 0,000 . It is lower than the significance level is 0.05 . It means $\mathrm{H} 1$ is accepted. Therefore, it can be concluded the role conflict has a negative effect on auditor performance.

2) Hypothesis test II (H2)

Table 2 shows the results of the $\mathrm{X} 2$ regression coefficient are -0.445 with a significance level is 0.000 which is lower than the real level is 0.05 . It means $\mathrm{H} 2$ is accepted. Therefore, it can be concluded the unclear role has a negative effect on auditor performance.

Table 3

\begin{tabular}{|c|c|c|c|c|c|}
\hline \multirow[t]{2}{*}{ Model } & \multicolumn{2}{|c|}{$\begin{array}{l}\text { Unstandardized } \\
\text { Coefficients }\end{array}$} & \multicolumn{3}{|c|}{$\begin{array}{l}\text { Standardize } \\
\text { d } \\
\text { Coefficients }\end{array}$} \\
\hline & $\mathrm{B}$ & Std. Error & Beta & $\mathrm{t}$ & Sig. \\
\hline \multirow{2}{*}{$\begin{array}{l}\text { (Constant) } \\
\text { Role conflict }\end{array}$} & 30.177 & 2.861 & & 10.549 & .000 \\
\hline & -.552 & .107 & -.679 & -5.152 & .000 \\
\hline
\end{tabular}

The results of moderation regression analysis

Dewi, N. P. R. A., \& Ramantha, I. W. (2019). Effect of conflict and unclear role on auditor performance with emotional quotient as moderating variable. International Journal of Social Sciences and Humanities, 3(3), 50-59. https://doi.org/10.29332/ijssh.v3n3.350 


\begin{tabular}{llllll}
\hline \multicolumn{1}{c}{ Unclear role } & -.904 & .159 & -.849 & -5.692 & .000 \\
$\quad$ Emotional & .690 & .189 & 2.657 & 3.655 & .001 \\
$\quad$ quotient & & & & & \\
$\mathrm{X}_{1} . \mathrm{X}_{3}$ & .297 & .100 & 1.183 & 2.981 & .004 \\
$\mathrm{X}_{2} . \mathrm{X}_{3}$ & .347 & .156 & 1.373 & 2.221 & .030 \\
R Square & & & & & 0,568 \\
Adjusted R Square & & & & & 0,528 \\
$\mathrm{~F}_{\text {count }}$ & & & & & 14,436 \\
Significance & & & & & 0,000 \\
\hline
\end{tabular}

Source: processed data (2019)

The regression equation is generated based on the moderation regression model.

$$
\begin{aligned}
& \mathrm{Y}=\mathrm{a}+\mathrm{b}_{1} \mathrm{X}_{1}+\mathrm{b}_{2} \mathrm{X}_{2}+\mathrm{b}_{3} \mathrm{X}_{3}+\mathrm{b}_{4} \mathrm{X}_{1} \mathrm{X}_{3}+\mathrm{b}_{5} \mathrm{X}_{2} \mathrm{X}_{3} \\
& Y=30,177-0,552 X_{1}-0,904 X_{2}+0,690 X_{3}+0,297 X_{1} X_{3}+0,347 X_{2} X_{3}
\end{aligned}
$$

3) Hypothesis test III (H3)

The moderation coefficient value with $b_{4}$-value is 0.297 with a significance is 0.004 indicated the influence of role conflict accompanied on adequate emotional quotient can improve auditor performance.

4) Hypothesis test IV (H4)

The moderation coefficient value with $b_{5}$-value is 0.347 with a significance is 0.030 indicated the influence of unclear role accompanied on adequate emotional quotient can improve auditor performance.

\section{Conclusion}

Based on the results and discussion above some conclusions can be drawn as follows:

1) Role conflict has a negative influence on auditor performance. It means the higher role conflict level held an auditor. The auditor's performance will decrease.

2) The unclear role has a negative influence on auditor performance. It means the higher level obscurity role held an auditor, the auditor's performance will decline.

3) The emotional quotient can weaken the negative influence of role conflict on auditor performance. It means the high emotional quotient can weaken the role conflict on PAF auditor performance in Bali province. Therefore, the auditor's performance will increase.

4) The emotional quotient can weaken the negative influence of role obscurity on auditor performance. It means the high emotional quotient can weaken the unclear role of PAF auditor performance in Bali province. Therefore, the auditor's performance will increase.

\section{Acknowledgments}

The authors would like to thank the reviewer for their consideration of the further process of the present paper. Thanks to the editor of IJSSH for the valuable support, time as well as advice. 


\section{References}

Afriana, Rheny. (2013). Pengaruh Struktur Audit, Konflik Peran, dan Ketidakjelasan Peran terhadap Kinerja Auditor. Jurnal Ekonomi Universitas Riau,

Amilin, A. (2017). The Impact of Role Conflict and Role Ambiguity on Accountants' Performance: The Moderating Effect of Emotional Quotient. European Research Studies, 20(2), 237.

Aprimulki, E., Kamaliah, K., \& Safitri, D. (2017). Pengaruh Konflik Peran, Kelebihan Peran, Independensi, dan Kompetensi terhadap Kinerja Auditor dengan Kecerdasan Spiritual sebagai Variabel Moderasi (Studi Empiris pada Kantor Akuntan Publik Pekanbaru dan Padang). Jurnal Online Mahasiswa Fakultas Ekonomi Universitas Riau, 4(1), 3124-3138.

Ermawati, M. D., Sinarwati, N. K., \& Edy Sujana, S. E. (2014). Pengaruh Role Stress Terhadap Kinerja Auditor dengan Emotional Quotient Sebagai Variabel Moderating (Studi Empiris pada Kantor Akuntan Publik di Bali).JIMAT Uurnal Ilmiah Mahasiswa Akuntansi) Undiksha, 2(1). http://dx.doi.org/10.23887/jimat.v2i1.2957

Govindarajan, V. (1986). Impact of participation in the budgetary process on managerial attitudes and performance: Universalistic and contingency perspectives. Decision Sciences, 17(4), 496-516. https://doi.org/10.1111/j.1540-5915.1986.tb00240.x

Hanna, E., \& Firnanti, F. (2013). Faktor-faktor yang Mempengaruhi Kinerja Auditor. Jurnal Bisnis dan Akuntansi, 15(1), 13-28. https://doi.org/10.34208/jba.v15i1.205

Hery. (2005). Etika Profesi dan Kepuasan Auditor. Media Akuntansi, Edisi 46/XII. Juni.

Ilman, Rizki. (2017). Pengaruh Konflik Peran dan Ketidakjelasan Peran terhadap Kinerja Auditor dengan Kecerdasan Emosional sebagai Variabel Moderating, Jurnal Akuntansi Fakultas Ekonomi Universitas Riau, $4(1)$.

Kurniawan, R. A. (2018). Pengaruh Konflik Peran dan Ketidakjelasan Peran terhadap Kinerja Auditor Internal (Studi pada Pstnt Batan Bandung). JASa (Jurnal Akuntansi, Audit dan Sistem Informasi Akuntansi), 2(3), 4353.

Mangkunegara, A. P., \& Prabu, A. (2009). Manajemen sumber daya manusia. Bandung: PT. Remaja Rosdakarya.

Marlita, Sherly. (2014). Pengaruh Konflik Peran, Ketidakjelasan Peran, Kesan Ketidakpastian Lingkungan, Locus of Control dan Motivasi Kerja terhadap Kinerja Auditor. Jurnal Ekonomi Universitas Riau. 21(4)

Patria, R., DP, E. N., \& Rusli, R. (2016). Pengaruh konflik peran dan ambiguitas peran terhadap kinerja auditor dengan kecerdasan emosional sebagai variabel moderasi (studi empiris pada KAP di Pekanbaru Padang dan Batam). Jurnal Online Mahasiswa Fakultas Ekonomi Universitas Riau, 3(1), 881-895.

Putra, I. G. B. W., \& Sudana, I. P. (2019). Effect of auditor's role conflict on auditor's stress with core selfevaluations as moderators. International Research Journal of Management, IT and Social Sciences, 6(4), 147155. https://doi.org/10.21744/irjmis.v6n4.669

Rahmawati. (2011). Pengaruh Role Stress terhadap Kinerja Auditor dengan Emotional Quotient sebagai Variabel Moderating. Jurnal Akuntansi Universitas Syarif Hdiayatullah Jakarta, 1(4), 40-69.

Saputra, L. A. A., Surati, -, \& Saufi, A. (2019). Mediation role of job satisfaction towards effect of conflict roles on organizational commitment. International Journal of Social Sciences and Humanities, 3(2), 165-175. https://doi.org/10.29332/ijssh.v3n2.308

Saraswati, A. A. S. D., \& Badera, I. D. N. (2018). Pengaruh Profesionalisme, Pengalaman Kerja, Konflik Peran dan Ketidakjelasan Peran Pada Kinerja Auditor KAP di Bali. E-Jurnal Akuntansi, 982-1007. https://doi.org/10.24843/EJA.2018.v23.i02.p07

Sari, N. P. E. R., \& Suryanawa, I. K. (2016). Konflik Peran, Ketidakjelasan Peran, dan Kelebihan Peran Terhadap Kinerja Auditor dengan Tekanan Waktu Sebagai Pemoderasi. E-Jurnal Akuntansi, 1392-1421.

Sari, W. (2017). Pengaruh konflik peran, ketidakjelasan peran, kelebihan peran, gaya kepemimpinan, struktur audit, dan pemahaman good governance terhadap kinerja auditor (Studi Empiris Pada Kantor Akuntan Publik Di Provinsi Jawa Tengah dan DIY) (Doctoral dissertation, UNIVERSITAS STIKUBANK SEMARANG).

Sarlito Sarwono, W. (2012). Pengantar psikologi umum.

Susatmoko, S., \& Sasongko, N. (2017). Pengaruh Gaya Kepemimpinan, Pemahaman Good Governance, Konflik Peran, dan Ketidakjelasan Peran Terhadap Kinerja Auditor dengan Kecerdasan Emosional Sebagai Variabel Pemoderasi (Studi Empiris Pada Kantor Akuntan Publik di Kota Semarang dan Surakarta) (Doctoral dissertation, Universitas Muhammadiyah Surakarta).

Dewi, N. P. R. A., \& Ramantha, I. W. (2019). Effect of conflict and unclear role on auditor performance with emotional quotient as moderating variable. International Journal of Social Sciences and Humanities, 3(3), 50-59. https://doi.org/10.29332/ijssh.v3n3.350 
Widyastary, I. A. P., Yasa, G. W., \& Wirakusuma, M. G. (2014). Pengaruh Konflik Peran, Ketidakjelasan Peran dan Kelebihan Peran pada Kinerja Auditor dengan Kecerdasan Emosional Sebagai Variabel Pemoderasi (Studi Empiris pada Kantor Akuntan Publik Se-Provinsi Bali). Simposium Nasional Akuntansi XVII.

Wiguna, M., Sari, R. N., \& Afifah, U. (2015). Pengaruh Role Conflict, Role Ambiguity, Self-efficacy, Sensitivitas Etika Profesi terhadap Kinerja Auditor dengan Emotional Quotient sebagai Variabel Moderating (Studi Empiris pada Kantor Akuntan Publik di Pekanbaru, Batam, dan Medan). Jurnal Online Mahasiswa Fakultas Ekonomi Universitas Riau, 2(1).

Winidiantari, P. N., \& Widhiyani, N. L. S. (2015). Pengaruh Konflik Peran, Ketidakjelasan Peran, Struktur Audit, Motivasi dan Kepuasan Kerja pada Kinerja Auditor. E-Jurnal Akuntansi, 249-264.

Yustiarti, F., \& Hasan, A. (2016). Pengaruh konflik peran, ketidakjelasan peran, dan kelebihan peran terhadap kinerja auditor dengan kecerdasan emosional sebagai pemoderasi (studi empiris pada kap di pekanbaru, padang dan medan). Jurnal Akuntansi (Media Riset Akuntansi \& Keuangan), 5(1), 12-28. 


\section{Biography of Authors}

\begin{tabular}{|l|l|}
\hline \hline & $\begin{array}{l}\text { Ni Putu Ria Arista Dewi, S.E. was born on March 28, 1994. She is master of } \\
\text { accounting student in Faculty of Economics and Business, Udayana University. She } \\
\text { lives on Jl. Raya Tebongkang, Ubud, Gianyar. She obtained her bachelor's degree at } \\
\text { Faculty of Economics and Business, Udayana University in } 2016 . \\
\text { Email: riaarista28@gmail.com }\end{array}$ \\
\hline \hline
\end{tabular}

Dewi, N. P. R. A., \& Ramantha, I. W. (2019). Effect of conflict and unclear role on auditor performance with emotional quotient as moderating variable. International Journal of Social Sciences and Humanities, 3(3), 50-59. https://doi.org/10.29332/ijssh.v3n3.350 